\title{
Hepatitis $C$ virus infection in blood donors from the state of Puebla, Mexico
}

\author{
Francisca Sosa-Jurado ${ }^{1,4}$, Gerardo Santos-López ${ }^{2 *}$, Belinda Guzmán-Flores ${ }^{1}$, Julia I Ruiz-Conde , \\ Daniel Meléndez-Mena ${ }^{3}$, Martín T Vargas-Maldonado ${ }^{1}$, Ygnacio Martínez-Laguna ${ }^{4}$, Laura Contreras-Mioni ${ }^{5}$, \\ Verónica Vallejo-Ruiz², Julio Reyes-Leyva ${ }^{2^{*}}$
}

\begin{abstract}
Background: Worldwide, 130 million persons are estimated to be infected with HCV. Puebla is the Mexican state with the highest mortality due to hepatic cirrhosis. Therefore, it is imperative to obtain epidemiological data on $\mathrm{HCV}$ infection in asymptomatic people of this region. The objective of present study was to analyze the prevalence of antibodies and genotypes of hepatitis $\mathrm{C}$ virus (HCV) in blood donors from Puebla, Mexico.

Results: The overall prevalence was 0.84\% (515/61553). Distribution by region was: North, 0.86\% (54/6270); Southeast, 1.04\% (75/7197); Southwest, 0.93\% (36/3852); and Central, 0.79\% (350/44234). Ninety-six donors were enrolled for detection and genotyping of virus, from which 37 (38.5\%) were HCV-RNA positive. Detected subtypes were: 1a (40.5\%), 1b (27.0\%), mixed 1a/1b (18.9\%), undetermined genotype $1(5.4 \%), 2 \mathrm{a}(2.7 \%), 2 \mathrm{~b}(2.7 \%)$, and mixed 1a/2a (2.7\%). All recovered donors with S/CO > 39 were HCV-RNA positive (11/11) and presented elevated ALT; in donors with S/CO < 39 HCV-RNA, positivity was of 30.4\%; and $70 \%$ had normal values of ALT. The main risk factors associated with HCV infection were blood transfusion and surgery.
\end{abstract}

Conclusions: HCV prevalence of donors in Puebla is similar to other Mexican states. The most prevalent genotype is 1 , of which subtype $1 \mathrm{a}$ is the most frequent.

\section{Background}

Hepatitis $\mathrm{C}$ virus (HCV) infection is an important public health concern. Worldwide, 130 million persons (prevalence of 2-2.2\%) are estimated to be infected. The primary diseases associated with $\mathrm{HCV}$ are chronic hepatitis, cirrhosis, and cellular hepatocarcinoma [1-3].

The actual prevalence of $\mathrm{HCV}$ is difficult to assess because serological tests do not discriminate among acute, chronic, or resolved infection, and the analyzed groups in most countries are not representative of the general population, such as blood donors, drug users, or individuals with high-risk sexual practices $[3,4]$.

$\mathrm{HCV}$ prevalence in Mexico has been analyzed in several studies, reporting an average of $1.4 \%$ in the open population and $35 \%$ in patients with active hepatitis [5]. Because $\mathrm{HCV}$ is relatively variable, it is currently grouped in six genotypes and several subtypes. In

\footnotetext{
* Correspondence: gerardo.santos.lopez@gmail.com; julio.reyes@imss.gob.mx ${ }^{2}$ Laboratorio de Biología Molecular y Virología, Centro de Investigación Biomédica de Oriente, Instituto Mexicano del Seguro Social; Metepec, Puebla, Mexico
}

Mexico, the prevalence of genotype 1 ranges from 30 to $87.5 \%$, with a predominance of subtypes $1 \mathrm{~b}$ and $1 \mathrm{a}$. Genotypes 2 and 3 are less frequent and genotypes 4-6 are unusual in Mexican subjects [6].

In Mexico, cirrhosis has shown an increasing tendency, rising from 12,058 cases in 2005 to 12,996 cases in 2006. In addition, cirrhosis is the second cause of death in the 15- to 64-year-old age group, being three times higher in men than in women. Puebla is the Mexican state with the highest mortality due to hepatic cirrhosis [7]. Therefore, it is imperative to obtain epidemiological data on the asymptomatic people, which may contribute to know, in part, the possible causes of the high incidence of hepatic diseases in this region.

The aim of this study was to know the epidemiological profile of relatively recent infected HCV individuals, detected as asymptomatic carriers and who were identified as blood donors in the State of Puebla, Mexico.

\section{() Biomed Central}




\section{Results}

\section{Seroprevalence of HCV}

From 61553 donors analyzed during the study period, $515(0.84 \%)$ were anti-HCV reactive. The overall prevalence descended from $0.93 \%$ in 2003 to $0.55 \%$ in 2006 (Figure 1). The mean prevalence at the more urbanized central (Angelopolis) region was $0.79 \%$ which includes the city of Puebla de los Angeles, the capital of the state. In the other regions, either suburban or rural, prevalence values ranged from 0.86 to $1.04 \%$ (Figure 2). No significant difference was observed among these regions (Student's t-test, $p>0.05$ ).

Low S/CO values (from 1.0 to 4.0 ) were found in $79 \%$ of reactive donors. The rest of the donors presented $\mathrm{S} /$ CO from 4.1 to 168 , which can be considered from medium to relatively high (Figure 3 ).

Of 515 reactive donors, 96 accepted to be included in the subsequent studies ("recovered" donors) and were interrogated and sampled from June 2005 and December 2006. From these 96 donors, $80 \%$ presented low S/ $\mathrm{CO}$ values (from 1.0 to 4.0 ) and the rest presented S/ $\mathrm{CO}$ from 4.1 to 168 (Figure 3 ). These data show that this sample of 96 donors is representative of the total population of donors previously analyzed.

\section{HCV-RNA detection}

Of the 96 recovered donors, 37 were $\mathrm{HCV}$-RNA positive (38.5\%). The anti-HCV S/CO ratio was related with positivity to HCV-RNA detection; $100 \%$ of donors with $\mathrm{S} / \mathrm{CO}>39$ were HCV-RNA positive, whereas donors with lower $\mathrm{S} / \mathrm{CO}$ values presented progressively reducing percentages of viral RNA detection. In donors with
S/CO from 1 to 2, HCV-RNA was detected only in $13.7 \%$ (Figure 4 ).

\section{Distribution of genotypes}

HCV genotypes and subtypes were analyzed in all 37 HCV-RNA positive recovered blood donors. 34 (91.8\%) donors had HCV genotype 1. Of these donors, 2 (5.4\%), $15(40.5 \%), 10(27.0 \%)$, and 7 (18.9\%) had subtypes 1 undetermined, $1 \mathrm{a}, 1 \mathrm{~b}$, and $1 \mathrm{a} / 1 \mathrm{~b}$, respectively. One donor had genotype $2 \mathrm{a}(2.7 \%)$ and another had subtype $2 \mathrm{~b}(2.7 \%)$. One donor $(2.7 \%)$ presented the mixed $1 \mathrm{a} / 2 \mathrm{a}$ genotypes (Table 1).

\section{Risk factors}

The main risk factors recognized in recovered donors were histories of surgery $(29.1 \%)$ and of blood transfusion $(6.2 \%)$, with 46 and $50 \%$ of HCV-RNA positive, respectively. Other important risk factors identified were history of migration (15.6\%), dental treatments (14.5\%), multiple sex partners (5.2\%), and living with infected family members $(4.16 \%)$. In $40.6 \%$ of the recovered donors the risk factor could not be identified.

\section{ALT levels in recovered blood donors}

Of $37 \mathrm{HCV}-\mathrm{RNA}$-positive donors, 11 (29.7\%) presented significantly high levels of ALT $(68.9 \pm 7.1 \mathrm{IU} / \mathrm{l})$. All donors HCV-RNA-negative presented normal levels of ALT $(30.6 \pm 5.6 \mathrm{IU} / \mathrm{l})$, which included individuals with anti-HCV S/CO from 1 to 16 .

\section{Age range of blood donors}

The mean age of the 515 reactive donors was 34.5 years, while that of the 96 recovered donors was 34.6. Among recovered donors, positive and negative HCV-RNA, there was no significant difference (34.7 and 38.1 years,

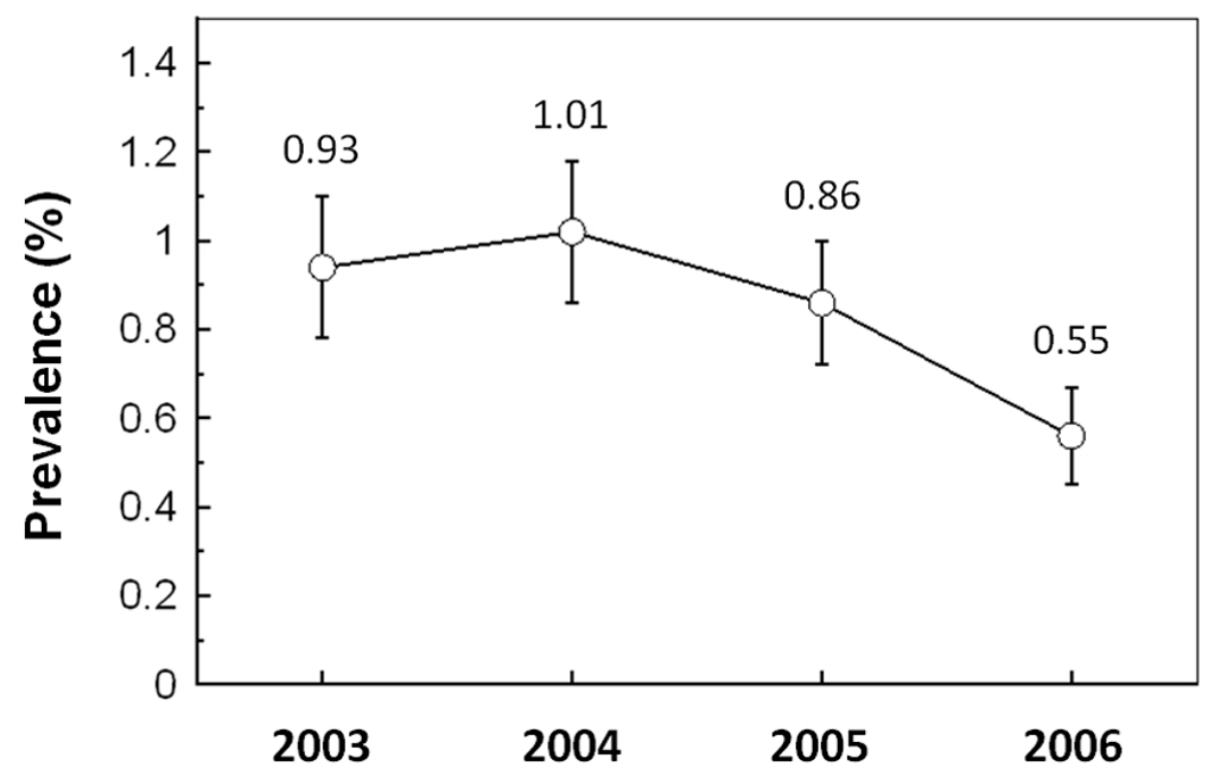

Figure 1 Prevalence rates of anti-HCV blood donors during the studied period in the state of Puebla. Specific anti-HCV antibodies were detected using the AxSYM HCV 3.0 assay (Abbott Diagnostics). Bars represent the 95\% confidence interval. 


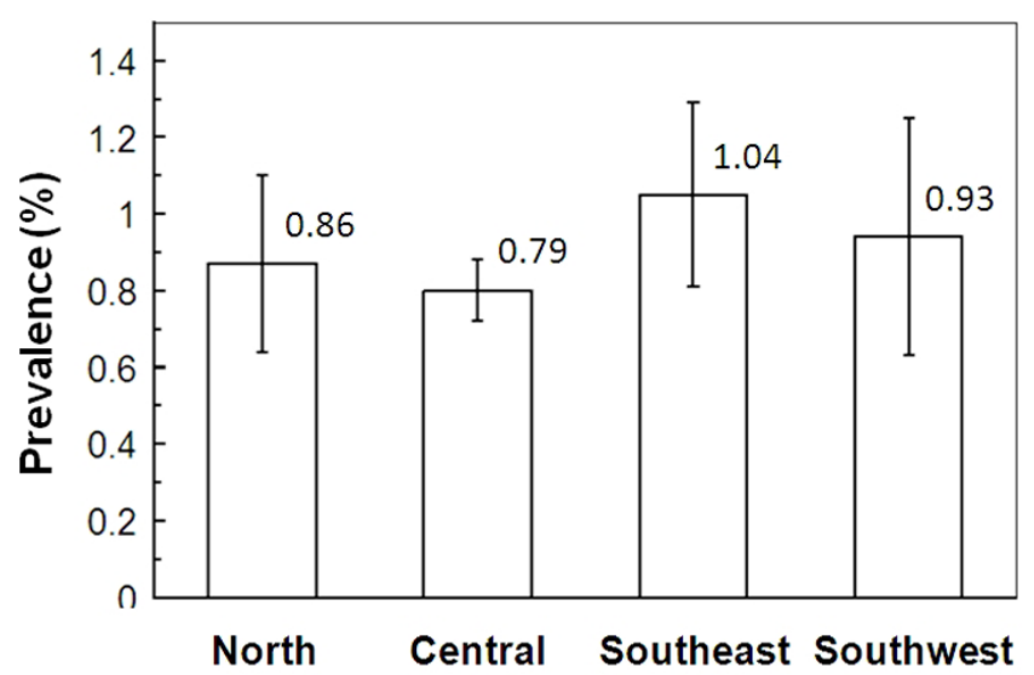

Figure 2 Distribution of prevalence rates of anti-HCV blood donors by region in the state of Puebla. The Central Region is known as "Angelopolis". Bars represent the 95\% confidence interval.

respectively; Student's t-test, $p=0.234$ ). On the other hand, the mean age of recovered HCV-RNA-positive donors was different between the individuals with antiHCV S/CO ratios ranging from 1 to 16 , and those with S/ $\mathrm{CO}>39$ (35.5; 95\% CI, 31.1-39.8 years and 43.3; 95\% CI, 38.4-48.3 years, respectively; Student's t-test, $p=0.044$ ).

\section{Discussion}

Blood donors are a low-risk population, usually presenting a lower prevalence than the open population. The overall prevalence obtained in the present work was
$0.84 \%$, this result is in agreement with other studies on the prevalence among donors in Mexico, which ranges from 0 to $2 \%$, but most of studies report values $>1 \%$ $[6,8]$. It is noteworthy that the prevalence values are descending since 2003 (Figure 1), probably due to the application of a more strict questionnaire to potential donors, as observed previously [9].

An essential item of the epidemiological profile of this type of studies are the risk factors that must be considered during the screening of blood donors in the questionnaire. In contrast to most studies on Mexican

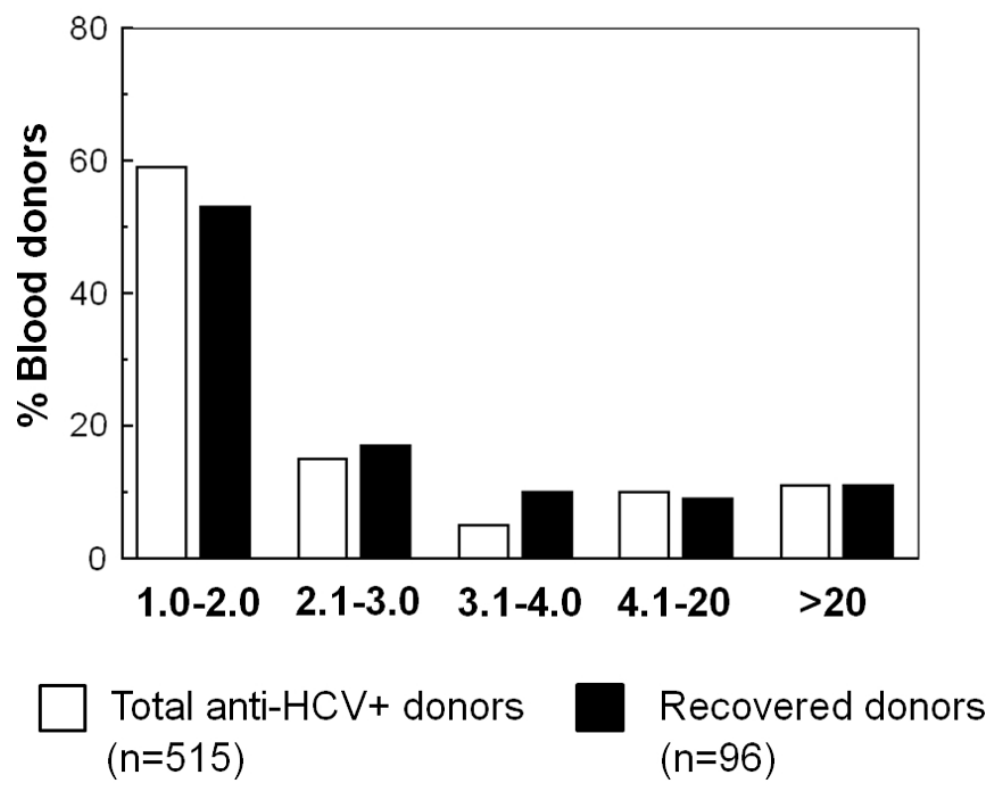

Figure 3 Distribution of donors (\%) according to anti-HCV (S/CO) values. Comparison of total versus recovered anti-HCV (+) donors, 


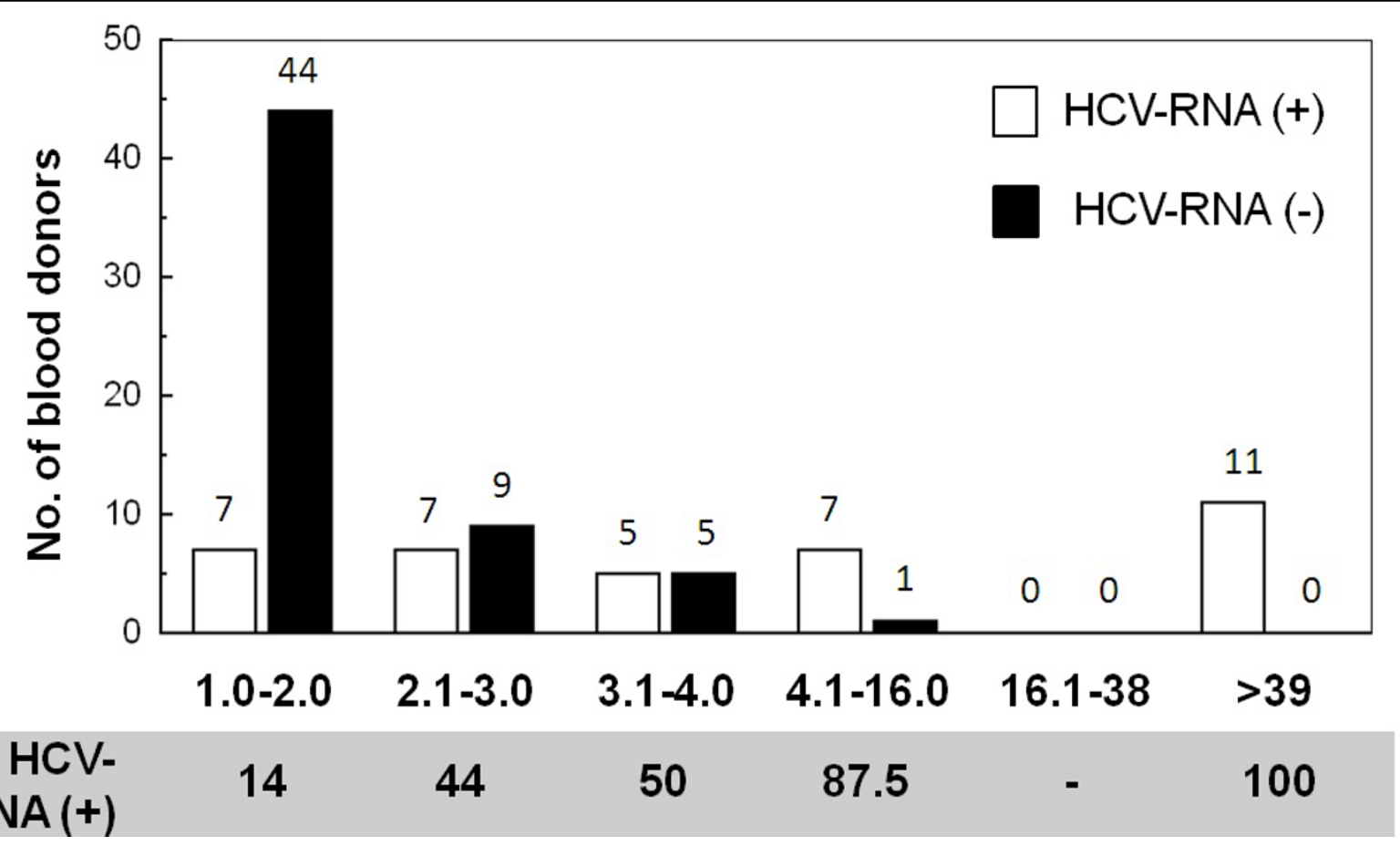

Figure 4 HCV-RNA positivity in recovered blood donors grouped by anti-HCV S/CO ratio values.

populations $[6,8]$, we registered as main risk factor the history of surgery with no prior history of blood transfusion, which was recognized in $29.1 \%$ of the anti-HCV positive recovered blood donors. Other studies in Puerto Rico [10] and India [11] have also reported surgery as a first-order risk factor.

Another important parameter is the antibody quantity, estimated by the S/CO ratio values in EIA. S/CO ratios ranged from 1 to 128 , and $80 \%$ of donors presented low $\mathrm{S} / \mathrm{CO}$ values (1-4.1), which represent false positive in the majority of cases. All donors were asymptomatic at the moment of sampling, the mean age of blood donors with $\mathrm{S} / \mathrm{CO}$ ranging from 1 to 4.1 was 35.5 years,

Table 1 Genotype and subtype of HCV in the 37 HCVRNA-positive recovered donors

\begin{tabular}{lll}
\hline Genotype/subtype & Frequency & Percentage (\%) \\
\hline $1^{*}$ & 2 & 5.4 \\
$1 \mathrm{a}$ & 15 & 40.5 \\
1b & 10 & 27.0 \\
1a/1b & 7 & 18.9 \\
Genotype 1 & 34 & 91.8 \\
2a & 1 & 2.70 \\
2b & 1 & 2.70 \\
Genotype 2 & 2 & 5.40 \\
1a/2a & 1 & 2.70 \\
Total & 37 & 100 \\
\hline
\end{tabular}

*Undetermined subtype. whereas in the donors with $\mathrm{S} / \mathrm{CO}>39$ it was 43.3 years. It is noteworthy that the mean age of Mexican infected patients with clinical symptoms has been calculated in 44 years [12], whereas that of Mexican patients with cirrhosis is 52 years [13].

On the other hand, donors with $\mathrm{S} / \mathrm{CO}>39$ presented significantly higher ALT values than donors with low S/ $\mathrm{CO}$, which has been observed also in other studies [14-16]; this could be related with a potential hepatic damage.

The HCV-RNA detection is one of the criteria to start therapy that depends also on genotype, viral load, and the degree of liver damage. However, of the 96 recovered donors, only 37 (38.5\%) were positive to HCV genome detection, and more than $60 \%$ of the anti-HCV positive individuals had no viremia. The presence of specific antibodies against HCV and absence of HCVRNA is a common finding and may be related with one of the following causes: a) the patient has resolved the infection eliminating the virus, b) the infection is so recent and there is no sufficient viral load to detect the virus and the patient should be continuously monitored, or c) there is a cross reaction with antibodies different from anti-HCV [17-21].

\section{Conclusions}

$\mathrm{HCV}$ prevalence among donors in the state of Puebla is similar to that of other Mexican states. The most 
prevalent genotype was 1 (91.7\%) and the most frequent subtype was $1 \mathrm{a}(40.5 \%)$. The main risk factors recognized in recovered donors were histories of surgery and of blood transfusion.

\section{Methods}

\section{Blood donors}

The study population consisted of individuals who donated blood between January 2003 and December 2006 from the State of Puebla, Mexico, at National Health Centre "Manuel Avila Camacho". During this period, 61553 first time donors were analyzed, and were subjected to routine studies by the Blood Bank, according to Mexican Official Standard, NOM-003-SSA2-1993, including a third generation EIA anti-HCV test. After that, we invited the positive anti-HCV donors to participate in this study that included HCV-RNA detection and quantification of alanine-aminotransferase (ALT) activity. Individuals who agreed to enter the study were classified as "recovered" donors. A questionnaire, requesting information on transfusion, surgical or dialysis history, piercing and tattooing, or sexual practices and other data, was applied to recovered donors.

\section{Detection of anti-HCV}

Screening of blood donors was performed using the AxSYM HCV 3.0 assay (Abbott Diagnostics, Wiesbaden, Germany). The AxSYM HCV 3.0 is an indirect microparticle enzyme immunoassay (MEIA) that detects human antibodies against recombinant $\mathrm{HCV}$ proteins core, NS3, NS4, and NS5. The values of antibody detection are expressed as the ratio between the signals detected in the sample and the cutoff value $(\mathrm{S} / \mathrm{CO})$; samples with $\mathrm{S} / \mathrm{CO}$ values $\geq 1.0$ were considered reactive [22]. All reactive samples were submitted to a second anti-HCV detection test.

\section{HCV RNA detection}

RNA in serum samples was extracted using QIAamp RNA Viral Mini Kit (Qiagen, Valencia, CA). HCV-RNA was amplified using a nested RT-PCR with the two sets of primers corresponding to the 5' UTR, either in the first or second round, as reported previously [23-25]. Reverse transcription and the first round of PCR $(25 \mu \mathrm{l}$ reactions) were performed using One-Step RT-PCR with Platinum Taq (Invitrogen, Carlsbad, CA). Program parameters were $55^{\circ} \mathrm{C}$ for $30 \mathrm{~min}$ (RT), $94^{\circ} \mathrm{C}$ for $2 \mathrm{~min}$, and 40 cycles of $94^{\circ} \mathrm{C}$ for $30 \mathrm{sec}, 56^{\circ} \mathrm{C}$ for $30 \mathrm{sec}$, and $72^{\circ} \mathrm{C}$ for $30 \mathrm{sec}$. The second round of PCR $(25 \mu \mathrm{l}$ reactions) was performed using BioMix (Bioline, London, UK) and $2 \mu \mathrm{l}$ of first-round PCR product. Thermal cycler conditions were $94^{\circ} \mathrm{C}$ for 2 min and 40 cycles of $94^{\circ} \mathrm{C}$ for 30 sec, $60^{\circ} \mathrm{C}$ for $30 \mathrm{sec}$, and $72^{\circ} \mathrm{C}$ for $30 \mathrm{sec}$. Nested RTPCR was performed by duplicate in all samples and reaction products were analyzed by $1 \%$ agarose gel electrophoresis. This home-made RT-PCR has a detection limit of $50 \mathrm{IU}$ per $\mathrm{ml}$ (unpublished results), which is comparable with commercial test used for qualitative detection of HCV genome [4].

\section{Genotyping analysis}

Viral genotypes were identified by restriction fragment length polymorphism (RFLP) according to published protocols [25]. Briefly, the 251-bp amplicon obtained in nested RT-PCR was digested with enzymes $M v a \mathrm{I}$ (Fermentas, Glen Burnie, MD) and Hinfl (Promega, Madison, WI) in order to discriminate among viral genotypes 1-6. After that, the 251-bp amplicon was digested with either Bst UI or ScrFI enzymes (New England Biolabs, Ipswich, MA) to identify viral subtypes. Restriction fragments were analyzed by $15 \%$ polyacrylamide gel electrophoresis.

Alanine-aminotransferase (ALT) determinations

ALT levels were measured with the Advia 1200 Chemistry System (Siemens healthcare Diagnostics Inc, Tarrytown, $\mathrm{NY}$ ) and the normal reference interval were 4-36 IU/l.

\section{Acknowledgements}

This work was supported by grants from CONACyT-Salud 2003-C01-085, IMSS-2004/111 and IMSS-2005/1///169. We wish to thank Dr. Alfonso Rodríguez Villegas, Medical Coordinator Management Group IMSS-Puebla, Medical Directors, Laboratory personnel and social workers of Rural Hospitals "Oportunidades" (\#89 Zacapoaxtla, \#86 Chignahuapan, Villa Avila Camacho (La Ceiba), \#88 El Seco, \#87 Chiautla de Tapia and \#77 Tepeji de Rodríguez). We thank also to Medical Directors and Research Coordinators of HGZ \#15 Tehuacán, HGZ \#23 Teziutlán and HGZ \#5 Metepec, Puebla, who helped to locate the sero-positive donors.

\section{Author details}

'Banco de Sangre, Hospital de Especialidades, Centro Médico Nacional Manuel Ávila Camacho, Instituto Mexicano del Seguro Social, Puebla, Puebla, Mexico. ${ }^{2}$ Laboratorio de Biología Molecular y Virología, Centro de Investigación Biomédica de Oriente, Instituto Mexicano del Seguro Social; Metepec, Puebla, Mexico. ${ }^{3}$ Clínica de Hepatitis, Servicio de Gastroenterología, Hospital de Especialidades, Centro Médico Nacional Manuel Ávila Camacho, Instituto Mexicano del Seguro Social, Puebla, Puebla, Mexico. ${ }^{4}$ Centro de Investigación en Ciencias Microbiológicas, Instituto de Ciencias, Benemérita Universidad Autónoma de Puebla, Puebla, Puebla, Mexico. ${ }^{5}$ Laboratorio Estatal de Salud Pública, Secretaria de Salud del Estado de Puebla, Puebla, Puebla, Mexico.

\section{Authors' contributions}

FSJ, GSL, YML, WR and JRL participated in the study design, molecular tests, in the data analysis and in drafting and discussing the manuscript. BGF, JIRC, MTVM and LCM carried out the serologic tests of blood donors. DMM received the 96 recovered donors in the Clinic of Hepatitis and assessments clinical and laboratory studies and participated in the analysis of clinicalepidemiological data. All authors read and approved the final manuscript.

\section{Competing interests}

The authors declare that they have no competing interests.

\section{Received: 1 December 2009}

Accepted: 25 January 2010 Published: 25 January 2010

\section{References}

1. Anonymous: Global burden of disease (GBD) for hepatitis C. J Clin Pharmacol 2004, 44:20-29.

2. Shepard CW, Finelli L, Alter MJ: Global epidemiology of hepatitis C virus infection. Lancet Infect Dis 2005, 5:558-567. 
3. Lavanchy D: The global burden of hepatitis C. Liver Int 2009, 29(Suppl 1):74-81.

4. Chevaliez S, Pawlotsky JM: Hepatitis C virus serologic and virologic tests and clinical diagnosis of HCV-related liver disease. Int J Med Sci 2006, 3:35-40.

5. Valdespino JL, Conde-Gonzáles JC, Olaiz FG, Palma O, D K, Sepulveda J: Seroprevalencia de la hepatitis $C$ en adultos de México: ¿un problema de salud pública emergente?. Salud Publica Mex 2007, 49:S395-S403.

6. Santos-Lopez G, Sosa-Jurado F, Vallejo-Ruiz V, Melendez-Mena D, ReyesLeyva J: Prevalence of hepatitis $C$ virus in the Mexican population: a systematic review. J Infect 2008, 56:281-290.

7. SSA: Morbilidad y mortalidad por cirrosis hepática. Salud: México 2006 México, D.F.: Secretaría de Salud 2007, 46-48.

8. Chiquete $E$, Panduro $A$ : Low prevalence of anti-hepatitis $C$ virus antibodies in Mexico: A systematic review. Intervirology 2007, 50:1-8.

9. Lopez RA, Romero-Estrella S, Infante-Ramirez L, Mendez-Aquino JS, BerronRuiz P, Morales-Alfaro NA, Vivar R, Carrada E, Rivera-Rendon Mdel R, Sanchez-Guerrero SA: Hepatitis $C$ seroprevalence in accepted versus deferred blood-donor candidates evaluated by medical history and selfexclusion form. Transfusion 2004, 44:1344-1349.

10. Rodriguez-Perez F, Suarez-Perez E, Alvarez-Rohena M, Toro DH: Prevalence of chronic hepatitis $C$ virus genotypes among patients between 21 to 65 years old in Puerto Rico. P R Health Sci J 2004, 23:49-56.

11. Thakral B, Marwaha N, Chawla YK, Saluja K, Sharma A, Sharma RR, Minz RW, Agnihotri SK: Prevalence \& significance of hepatitis $C$ virus $(\mathrm{HCV})$ seropositivity in blood donors. Indian J Med Res 2006, 124:431-438.

12. Rivas-Estilla AM, Cordero-Perez P, Trujillo-Murillo Kdel C, Ramos-Jimenez J, Chen-Lopez C, Garza-Rodriguez Mde L, Ramirez-Gutierrez A, MunozEspinosa $\mathrm{L}$ : Genotyping of hepatitis $\mathrm{C}$ virus $(\mathrm{HCV})$ in infected patients from Northeast Mexico. Ann Hepatol 2008, 7:144-147.

13. Gongora-Biachi RA, Castro-Sansores CJ, Gonzalez-Martinez P, LaraPerera DM, Garrido-Palma J, Lara-Perera V: Frequency of antibodies against the hepatitis C virus in patients with hepatic cirrhosis in Yucatan, Mexico. Salud Publica Mex 2003, 45:346-350.

14. Alter MJ, Kuhnert WL, Finelli L: Guidelines for laboratory testing and result reporting of antibody to hepatitis C virus. Centers for Disease Control and Prevention. MMWR Recomm Rep 2003, 52:1-13, 15; quiz CE11-14.

15. Goncales NS, Costa FF, Vassallo J, Goncales FL Jr: Diagnosis of hepatitis C virus in Brazilian blood donors using a reverse transcriptase nested polymerase chain reaction: comparison with enzyme immunoassay and recombinant protein immunoblot assay. Rev Inst Med Trop Sao Paulo 2000, 42:263-267.

16. Dufour DR, Talastas M, Fernandez MD, Harris B, Strader DB, Seeff LB: Lowpositive anti-hepatitis $C$ virus enzyme immunoassay results: an important predictor of low likelihood of hepatitis C infection. Clin Chem 2003, 49:479-486.

17. Ren FR, Lv QS, Zhuang H, Li JJ, Gong XY, Gao GJ, Liu CL, Wang JX, Yao FZ, Zheng YR, et al: Significance of the signal-to-cutoff ratios of anti-hepatitis $C$ virus enzyme immunoassays in screening of Chinese blood donors. Transfusion 2005, 45:1816-1822.

18. MacKenzie WR, Davis JP, Peterson DE, Hibbard AJ, Becker G, Zarvan BS: Multiple false-positive serologic tests for HIV, HTLV-1, and hepatitis $C$ following influenza vaccination, 1991. JAMA 1992, 268:1015-1017.

19. Contreras AM, Tornero-Romo CM, Toribio JG, Celis A Orozco-Hernandez A, Rivera PK, Mendez C, Hernandez-Lugo Ml, Olivares L, Alvarado MA: Very low hepatitis $C$ antibody levels predict false-positive results and avoid supplemental testing. Transfusion 2008, 48:2540-2548.

20. Hyland C, Seed CR, Kiely P, Parker S, Cowley N, Bolton W: Follow-up of six blood donors highlights the complementary role and limitations of hepatitis C virus antibody and nucleic acid amplification tests. Vox Sang 2003, 85:1-8

21. Baba SS, Fagbami AH, Olaleye OD: Antigenic relatedness of selected flaviviruses: study with homologous and heterologous immune mouse ascitic fluids. Rev Inst Med Trop Sao Paulo 1998, 40:343-349.

22. Hennig $H$, Schlenke $P$, Kirchner $H$, Bauer I, Schulte-Kellinghaus B, Bludau $H$ : Evaluation of newly developed microparticle enzyme immunoassays for the detection of HCV antibodies. J Virol Methods 2000, 84:181-190.

23. Garson JA, Tedder RS, Briggs M, Tuke P, Glazebrook JA, Trute A, Parker D, Barbara JA, Contreras M, Aloysius S: Detection of hepatitis C viral sequences in blood donations by "nested" polymerase chain reaction and prediction of infectivity. Lancet 1990, 335:1419-1422.
24. Okamoto $\mathrm{H}$, Kanai $\mathrm{N}$, Mishiro S: Full-length nucleotide sequence of a Japanese hepatitis C virus isolate (HC-J1) with high homology to USA isolates. Nucleic Acids Res 1992, 20:6410.

25. Davidson F, Simmonds P, Ferguson JC, Jarvis LM, Dow BC, Follett EA, Seed CR, Krusius T, Lin C, Medgyesi GA, et al: Survey of major genotypes and subtypes of hepatitis $C$ virus using RFLP of sequences amplified from the 5' non-coding region. J Gen Virol 1995, 76(Pt 5):1197-1204.

doi:10.1186/1743-422X-7-18

Cite this article as: Sosa-Jurado et al:: Hepatitis C virus infection in blood donors from the state of Puebla, Mexico. Virology Journal 2010 7:18.

\section{Submit your next manuscript to BioMed Central and take full advantage of:}

- Convenient online submission

- Thorough peer review

- No space constraints or color figure charges

- Immediate publication on acceptance

- Inclusion in PubMed, CAS, Scopus and Google Scholar

- Research which is freely available for redistribution 